\title{
Dinamika Relasi Orang Tua Dan Remaja Sebagai Upaya Prediksi Outcomes Pembentukan Karakter
}

\author{
Yuliana Intan Lestari \\ Universitas Islam Negeri Sultan Syarif Kasim Riau \\ anayuliana.psikologi@uin-suska.ac.id
}

\begin{abstract}
Abstrak
Kompleksitas perubahan dan permasalahan yang dihadapi oleh remaja berdampak besar bagi pembentukan karakter mereka sebagai outcomes diri yang mampu membantu menjalankan tugas-tugas perkembangan. Sebagai upaya dalam memprediksi karakter remaja dewasa ini diperlukan relasi orangtua dan remaja yang baik dalam segala hal. Mendidik remaja merupakan bagian terpenting dari orangtua agar dapat membentuk mereka sesuai harapan. Tidaklah mudah dalam mendidik anak, hal ini berkaitan dengan bagaimana peran aktif orangtua dalam memberikan pola atau gaya pengasuhan dalam mendidik. Pola asuh yang diterapkan sangat berpengaruh dalam memprediksi outcomes pembentukan karakter remaja. Karakteristik orang tua, tugas perkembangan keluarga, pola asuh yang dijalani, kompleksitas dinamika perubahan yang terjadi pada remaja, konflik yang terjadi antara remaja dengan orangtua dan konflik remaja dengan teman sebaya, serta tantangan orangtua dalam membimbing remaja dalam bidang akademik dan pendidikan seksualitas adalah faktor-faktor yang ikut memberikan kontribusi dalam pembentukan karakter sebagai outcomes dari remaja.
\end{abstract}

Kata kunci: Pembentukan Karakter, Relasi Orangtua-Remaja

\begin{abstract}
The complexity of change and problems that faced by adolescents has a major impact on the formation of their character as self-outcomes that are able to help carry out developmental tasks. As an effort to predict the character of adolescents today, good parent-adolescent relationships are needed in all respects. Educating teenagers is the most important part of parents in order to shape them according to expectations. It is not easy to educate children, this is related to how the active role of parents is in providing patterns or styles of parenting in educating. The parenting style that is applied is very influential in predicting the character building outcomes of adolescents. The characteristics of parents, the task of family development, the parenting patterns undertaken, the complexity of the dynamics of change that occur in adolescents, conflicts that occur between adolescents and parents and conflicts between adolescents and peers, and challenges of parents in guiding adolescents in academics and sexuality education are factors that contribute to the character building as the outcomes of adolescents.
\end{abstract}

Keyword: character building, parent-adolescent relationship 


\section{Pendahuluan}

Keluarga merupakan sekelompok orang yang disatukan oleh ikatan darah, pernikahan ataupun adopsi yang membentuk satu rumah tangga; dimana mereka menunjukkan peran saling menghormati antara suami dan istri, anak lelaki dan perempuan, ibu dan ayah, kakak dan adik dan membentuk budaya yang sama (Wilkinson, 1993). Keluarga, siklus, fungsi, dan strukturnya menjadi perhatian dalam penelitian karena hal-hal tersebut ditengarai menjadi faktor yang penting untuk memahami perkembangan individu. Fungsi keluarga dapat menjelaskan bagaimana cara-cara individu dalam keluarga mengembangkan koping dan mengatasi permasalahannya, karenanya mungkin terkait juga dengan status kesehatan mental individu. Keluarga juga dapat mempengaruhi bagaimana individu menjalin relasi sosial dengan orang di sekitarnya (Wilkinson, 1993).

Kaitan antara siklus hidup keluarga dengan perkembangan telah dikaji oleh Erikson dalam delapan tahap perkembangan psikososialnya. Pada masing-masing tahap dijelaskan peranan keluarga yang dinamis dalam menyesuaikan perkembangan individu yang juga bersifat dinamis dengan delapan titik krisis yang berbeda. Perbedaan perlakuan keluarga terhadap anggota keluarganya dapat menyebabkan perbedaan arah perkembangan bagi individunya. Peran keluarga yang dalam hal ini adalah orang tua mencakup pemberian nilai-nilai kehidupan bagi remajanya.

Penelitian ini mengkaji nilai-nilai apa saja yang diberikan oleh orang tua kepada remaja dalam membangun kepribadian yang baik pada diri remaja. Sebagaimana yang kita ketahui bahwa isu perkembangan remaja dalam Erikson adalah identitas lawan kebingungan identitas (identity versus role confusion) (Santrock, 2001). Pada masa ini, remaja dihadapkan pada penyesuaian baru dengan dirinya yaitu pubertas dan awal masa remaja. Anak mulai mengembangkan identitas diri dalam kaitannya dengan peran seksual, pribadi, aktivitas terkait. Proses ini harus didukung oleh significant others (orang-orang bermakna) agar remaja mendapatkan kekuatan dan kejelasan identitas dirinya (Wilkinson, 1993). Kejelasan identitas diri membuat remaja mengenal kekuatan/potensi dirinya maupun kelemahan/keterbatasan dirinya sehingga mudah baginya untuk fokus menentukan arah perkembangan selanjutnya seperti pilihan pasangan hidup, pilihan karir, pilihan teman dan sebagainya.

Significant others pada remaja sebenarnya terdapat pada hubungannya dengan teman sebaya (peers group). Namun sukses tidaknya seorang remaja menjalin hubungan tersebut juga ditentukan oleh bagaimana hubungan remaja dengan keluarganya. Penelitian-penelitian banyak mengungkapkan kaitan antara pola dan struktur keluarga dan output remaja yang dihasilkan. Misalnya relasi yang positif antara orangtua-remaja ternyata berkaitan dengan kesejahteraan subyektif remaja (Ben-Zur, 2003). Kesejahteraan subyektif itu sendiri merupakan indikator bagi kesuksesan remaja dalam kehidupannya. Hal tersebut diperkuat oleh Petit, dkk (2009) yang menemukan bahwa remaja dari keluarga yang tidak terlibat dalam proses mendidik, pemberian nilai- 
nilai kehidupan, kegiatan akademik dan pengawasan terhadap remaja cenderung tidak disukai oleh teman sebayanya.

Goldstein, Kean \& Ecles (2005) menyatakan bahwa mustahil untuk mempelajari hubungan remaja-teman sebaya tanpa mempertimbangkan keluarga yang memberi fasilitas hubungan tersebut. Penelitiannya juga mengungkap bahwa remaja yang bergaul dengan teman sebaya tanpa pengawasan orangtua sangat beresiko untuk terjebak dalam kegiatan-kegiatan yang berbahaya. Oleh karena itu perlu diketahui nilainilai kehidupan apa saja yang paling berpengaruh yang diberikan orang tua kepada remaja, yang akan mempengaruhi keberhasilan atau ketidakberhasilan perkembangan seorang remaja melalui fasenya dan melaksanakan tugas perkembangannya dengan baik menuju kepada pembentukan karakter yang baik.

Mendidik anak merupakan bagian terpenting dari orangtua agar dapat membentuk anak sesuai harapan. Tidaklah mudah dalam mendidik anak, hal ini berkaitan dengan bagaimana peran aktif orangtua dalam memberikan pola atau gaya dalam mendidik. Pola asuh yang diterapkan sangat berpengaruh dalam membentuk karakter anak. Menurut Widajat (2011) secara umum, pendidikan karakter sebagai upaya yang dengan sadar dirancang untuk membantu individu mengembangkan pengetahuan, keterampilan, dan kepribadiannya. Sedangkan karakter, diartikan oleh Sudrajat (2010) sebagai nilai-nilai perilaku manusia yang berhubungan dengan Tuhan Yang Maha Esa, diri sendiri, sesama manusia, lingkungan dan kebangsaan yang terwujud dalam pikiran, sikap, perasaan, perkataan dan perbuatan berdasarkan normanorma agama, hukum, tata krama, budaya dan adat istiadat.

Karakter (character) mengacu pada serangkaian sikap (attitudes), perilaku (behaviors), motivasi (motivations) dan keterampilan (skilss). Menurut Musfiroh (2008) karakter meliputi sikap seperti keinginan untuk melakukan hal yang terbaik, kapasitas intelektual seperti berfikir kritis dan alasan moral, perilaku seperti berkata jujur dan bertanggungjawab, mempertahankan prinsip-prinsip moral dalam situasi penuh ketidakadilan, kecakapan interpersonal dan emosional yang memungkinkan seseorang berinteraksi secara efektif dalam berbagai keadaan dan komitmen untuk berkontribusi dengan komunitas dan masyarakatnya. Karakteristik adalah realisasi perkembangan positif sebagai individu (intelektual, sosial, emosional dan etika). Individu yang berkarakter baik adalah seseorang yang berusaha melakukan hal yang terbaik.

Selanjutnya Sudrajat (2010) menyatakan bahwa 'pendidikan karakter adalah sistem penanaman nilai-nilai karakter kepada anak yang meliputi komponen pengetahuan, kesadaran atau kemauan, dan tindakan untuk melaksanakan nilai-nilai tersebut, baik kepada Tuhan Yang Maha Esa, diri sendiri, sesama, lingkungan, maupun kebangsaan sehingga menjadi manusia insan kamil”.

Keluarga adalah lembaga pendidikan pertama yang mempunyai peranan penting dalam membentuk karakter dan watak anak (Ajisuksmo, 2010). Keluarga mempunyai peranan penting dalam membentuk jati diri dan pembentukan karakter anak. Karakter bukan sekedar hasil dari sebuah tindakan melainkan secara simultan merupakan hasil 
dan proses (Santrock, 2008). Karakter erat kaitannya dengan personality (kepribadian) seseorang, dimana seseorang dapat disebut orang yang berkarakter (a person of character) jika tingkah lakunya sesuai dengan kaidah moral. Keluarga mempunyai peranan dalam membentuk alam spiritual dan moral anak. Anak-anak saat ini adalah orang yang masih memerlukan bimbingan. Dengan demikian merupakan suatu kaharusan untuk memberikan perhatian yang intensif kepada mereka sejak mereka lahir ke dunia.

\section{Pembahasan}

Keluarga tumbuh dan berkembang secara unik dan berbeda-beda, namun terdapat pola-pola umum yang dijalani dengan variasi-variasi tertentu. Dalam kaitannya dengan tahap relasi di keluarga, keluarga dengan anak remaja mendapatkan krisis permasalahan yaitu mengindividuasi remaja; pubertas dan perkembangan seksual. Duvall (dalam Friedman, 1998) menyebutkan tiga tugas penting keluarga dengan anak remaja yaitu : 1) Menyeimbangkan tanggung jawab dan kebebasan menuju kematangan dan meningkatkan kemandirian remaja, 2) kembali memfokuskan hubungan perkawinan antara suami dan istri, 3) membuka komunikasi antara anak dan orangtua.

Banyak ahli perkembangan menyepakati bahwa usia remaja diawali sejak 12 tahun (Hurlock, 1981; Monks 2000 dan Santrock, 2003). Namun bervariasi dalam menetapkan usia akhir remaja, Hurlock (1981) menetapkan 18 tahun, Monks (2000) menetapkan 21 dan Santrock (2003) menetapkan usia 23 tahun atau setara dengan lulus S1. Masa remaja sendiri dikatakan sebagai masa yang khusus, khas dan istimewa dimana terjadi loncatan perkembangan seperti halnya perkembangan pada masa awal kanak-kanak. Perkembangan tersebut terjadi antara lain pada aspek :

a. Perkembangan Fisik

Pubertas (puberty) ialah suatu periode dimana kematangan kerangka dan seksual terjadi secara pesat terutama pada masa remaja. Akan tetapi, pubertas bukan merupakan suatu peristiwa tunggal yang tiba-tiba terjadi. Pubertas merupakan bagian dari suatu proses yang terjadi berangsur-angsur (gradual), ditandai dengan menarche atau menstruasi yang pertama untuk perempuan dan mimpi basah untuk laki-laki.

Faktor dibalik munculnya kumis pertama pada anak laki-laki dan melebarnya pinggul pada anak perempuan adalah banjir hormon, yaitu zat-zat kimia yang sangat kuat yang disekresikan oleh kelenjar-kelenjar endokrin dan di bawa ke seluruh tubuh oleh aliran darah (Dyk, 1993 dalam Santrock, 2002). Konsentrasi hormon-hormon tertentu meningkat secara dramatis selama masa remaja (Rabin \& Chrousos, 1991; Susman \& Dorn, 1991, dalam Santrock, 2002). Testosteron (testosterone) ialah suatu hormon yang berkaitan dengan perkembangan alat kelamin, bertambahnya tinggi badan, dan perubahan suara pada anak laki-laki. Estradiol ialah suatu hormon yang berkaitan dengan perkembangan buah dada, rahim, dan kerangka pada anak-anak perempuan. 
Pertumbuhan tulang rangka tidak terjadi secara bersamaan, sehingga pada suatu fase, tubuh remaja terlihat aneh, panjang tangan dan kakinya tidak diikuti dengan perkembangan otot sehingga mereka terlihat sangat kurus dan rapuh seperti hendak jatuh bila disentuh. Belum lagi pertumbuhan hidung yang cepat di masa ini, namun wajah belum melebar sehingga seolah-olah wajah mereka berisi hidung melulu, dan tentu saja ada masalah lain, yaitu munculnya jerawat. Hal ini merisaukan remaja dan menimbulkan ketidakpuasan tertentu terhadap fisiknya yang belum sempurna berkembang itu. Seringkali mereka menjadi sangat sensitif terhadap kritikan dan pemarah. Mereka juga banyak memperhatikan kebutuhan fisiknya seperti bersolek dan mematut-matut diri di kaca. Keluarga juga harus memahami hal ini sebagai bentuk perubahan yang harus diadaptasi. Orangtua sangat berperan dalam membantu remaja melalui fase ini, karena bagi remaja, "ketidakpastian" bentuk tubuh ini jelas sangat merisaukan.

Selain pertumbuhan fisik yang tidak serentak terjadi, pertumbuhan tersebut juga memiliki pola naik dan turun, menyebabkan perubahan tingkah laku remaja yang terlihat sebagai "anak sulit." Mereka kadangkala menjadi sangat aktif, optimis, banyak bergerak dan beraktivitas dan mudah bekerjasama, namun pada fase turun mereka menjadi lambat dan terkesan seperti apa yang dikatakan orangtua sebagai "pemalas." Orangtua dan anggota keluarga lainnya harus memahami hal tersebut sebagai proses perkembangan sehingga tidak menimbulkan konflik pada hubungan di dalam keluarga.

b. Perkembangan Kognitif

Perkembangan kognitif remaja, dalam pandangan Jean Piaget (seorang ahli perkembangan kognitif) merupakan periode terakhir dan tertinggi dalam tahap pertumbuhan operasi formal (period of formal operations). Pada periode ini, idealnya para remaja sudah memiliki pola pikir sendiri dalam usaha memecahkan masalahmasalah yang kompleks dan abstrak. Kemampuan berpikir para remaja berkembang sedemikian rupa sehingga mereka dengan mudah dapat membayangkan banyak alternatif pemecahan masalah beserta kemungkinan akibat atau hasilnya. Kapasitas berpikir secara logis dan abstrak mereka berkembang sehingga mereka mampu berpikir multi-dimensi seperti ilmuwan. Para remaja tidak lagi menerima informasi apa adanya, tetapi mereka akan memproses informasi itu serta mengadaptasikannya dengan pemikiran mereka sendiri. Mereka juga mampu mengintegrasikan pengalaman masa lalu dan sekarang untuk ditransformasikan menjadi konklusi, prediksi, dan rencana untuk masa depan. Dengan kemampuan operasional formal ini, para remaja mampu mengadaptasikan diri dengan lingkungan sekitar mereka.

Pada masa inilah remaja mulai aktif membangun nilai dan moral sendiri dengan menyerap informasi dari lingkungannya. Remaja akan membandingkan nilai dan norma yang dianut keluarganya dengan nilai dan norma yang dijumpai di lingkungannya. Permasalahan akan muncul apabila terjadi perbedaan antara nilai keluarga dengan nilai yang diinternalisasi remaja dari lingkungannya. Perdebatan-demi perdebatan akan diselenggarakan dalam usaha remaja mematangkan nilai dan norma mana yang akan 
menjadi bagian dari moralitasnya. Orangtua yang lebih matang dalam hal ini akan merasakan adanya penolakan dan atau perlawanan dari remaja. Apabila hal tersebut tidak disadari orangtua sebagai bagian dari perubahan remaja, maka konflik akan muncul dalam kaitan hubungan keduanya. Penting bagi keluarga untuk bersikap fleksibel terhadap perubahan pikiran remaja dan berusaha untuk berkompromi daripada berkonfrontasi.

\section{c. Kognisi Sosial}

Perubahan-perubahan yang mengesankan dalam kognisi sosial menjadi ciri perkembangan remaja. Remaja mengembangkan sutu egosentrisme khusus, mulai berfikir tentang kepribadian. Pemikiran remaja bersifat egosentris. David Elkind (1976) dalam Santrock, 2002. Yakin bahwa egosentrisme remaja (adolescent egocentrism) memiliki dua bagian: penonton khayalan dan dongeng pribadi. Penonton khayalan (imaginary audience) ialah keyakinan remaja bahwa orang lain memperhatikan dirinya sebagaimana halnya dengan dirinya sendiri. Perilaku mengundang perhatian yang mencerminkan egosentrisme dan keinginan untuk tampil diatas pentas, diperhatikan dan dilihat. Sedangkan Dongeng pribadi (the personal fable) ialah bagian dari egosentrisme remaja yang meliputi perasaan unik seorang anak remaja. Rasa unik pribadi remaja membuat mereka merasa bahwa tidak seorangpun dapat mengerti bagaimana perasaan mereka sebenarnya. Hal ini membuat remaja sendiri membangun "benteng" dari orangtuanya dan menganggap mereka tidak dapat mengerti perasaan mereka dan memilih teman sebaya yang dianggap memiliki "nasib" yang sama. Hal ini membuat remaja cenderung dekat dengan teman sebaya daripada dengan anggota keluarga. Sikap remaja ini harus dimengerti oleh anggota keluarga lainnya, terutama oleh orangtua.

Sistem dalam keluarga sangat mempengaruhi perkembangan seseorang. Salah satu sistem tersebut terletak dalam hubungan orangtua-remaja dalam konteks pengasuhan. Pengasuhan sendiri terkait dengan hubungan antara ayah dan ibu yang mempengaruhi bagaimana cara orangtua menghadapi anak. Pengasuhan yang buruk cenderung berkorelasi dengan masalah-masalah pada anak (Haring\&Sabatteli, 1998).

Ketika anak pertama beranjak remaja (memasuki usia 12 tahun), usia orangtua biasanya telah berada pada usia 35-40 tahunan. Penekanan pada anak pertama bukan berarti mengecilkan arti anak ke dua, tiga dan seterusnya namun lebih ke arah momen atau pengalaman pertama menghadapi remaja pertama biasanya diaplikasikan pada anak-anak selanjutnya. Usaha menyesuaikan dengan karakteristik remaja, kebutuhan dan tuntutannya juga tergantung pada bagaimana karakteristik dari orangtua secara terpisah (ayah dan ibu) serta karakteristik pasangan (ayah dan ibu sebagai satu kesatuan yang juga saling menyesuaikan).

Karakteristik remaja yang syarat dinamika dan perubahan serta karakteristik orangtua yang juga berkembang menimbulkan penyesuaian yang terus menerus antara kedua belah pihak. Tidak jarang dalam proses tersebut muncul permasalahanpermasalahan yang khas pada keluarga dengan anak remaja. Wilkinson (1993) menuliskan bahwa permasalahan umum keluarga adalah perjuangan otonomi yang 
dicirikan dengan masalah yang muncul (overt) yaitu : pemberontakan, prestasi akademik yang rendah perilaku menentang yang dimunculkan remaja sebagai respon orangtua yang merasa benar sendiri sehingga konsep menghadapi remaja diwarnai tekad kuat untuk "memperbaiki anak." Remaja bisa saja protes namun seringkali merasa takut dan ambigu tentang tumbuh besar. Adapun masalah yang tersembunyi (covert) biasanya dialami oleh remaja yang merasa terbelah antara menjaga loyalitas dengan keluarga dan keinginan untuk terpisah dari orangtua (Wilkinson, 1993).

Namun sebenarnya, permasalahan remaja-orangtua dipengaruhi oleh hubungan yang telah mereka jalin sebelumnya dan sejauhmana masing-masing pihak memahami perubahan karakter dan kebutuhan pihak lainnya. Di sisi lain, konflik yang terbangun antara orangtua-remaja dapat dikatakan memiliki dampak yang positif bagi perkembangan keduanya. Pertentangan dengan orangtua dapat mendukung remaja mengklarifikasikan identitas, mencoba memahami perspektif orang lain dan menguasai permasalahan moral, belajar untuk kompromi dan mengatasi frustrasi serta kemarahan.

Kehidupan remaja yang penuh dengan kompleksitas permasalahan sosial yang muncul menyebabkan terjadi perubahan karakter kearah yang tidak sesuai dengan harapan sosial. Seringkali remaja hanya dipenuhi kebutuhan jasmaninya (makan, pakaian, mainan, tempat tinggal, biaya sekolah) tapi melupakan kebutuhan ruhaninya (kasih sayang, belaian, canda tawa, dialog dari hati, khususnya ilmu spiritual) sehingga mereka tumbuh menjadi remaja-remaja yang kering dan hampa. Generasi seperti ini tentunya sulit diharapkan untuk menjadi pencerah peradaban, karena mereka hanya kuat di "fisik" namun sangat rapuh "ruh"nya. Dengan demikian orangtua masa depan ini akan tumbuh dengan sempurna jika telah mendapatkan apa yang menjadi kebutuhan ruhaniah, mendapatkan pengarahan dan petunjuk yang baik dari pola asuh yang baik pula. Perhatian yang menyeluruh dalam segala aspek mulai dari aspek spiritual, intelektual, fisik, akhlak dan aspek pendidikan harus diberikan orangtua. Terutama pengaruh yang bernuansa religiusitas dan berlandaskan agama.

Pendidikan yang diberikan kepada remaja dimulai dari mereka masih anak-anak akan memiliki pengaruh yang besar bagi perkembangan jiwa mereka. Masa ini adalah masa persiapan dan pengarahan bagi remaja. Berdasarkan latar fenomena yang terjadi masa sekarang ini perlu upaya pembentukan karakter remaja salah satunya melalui pola asuh spiritual dalam keluarga. Spiritual parenting merupakan sistem pengasuhan remaja dengan paradigma menanamkan keimanan dan kesadaran rohani. Pendidikan keagamaan di sekolah saja tidak cukup untuk membangun spiritualitas remaja (Jahja, 2011).

Menurut Budiningsih (2004) karakter dapat terbentuk dipengaruhi oleh faktor internal dan eksternal. Faktor eksternal yang sangat mempengaruhi pembentukan karakter seseorang menjadi baik atau tidak baik adalah lingkungan keluarga dan lingkungan sosial. Nilai-nilai yang berkembang di dalam keluarga dan pola pengasuhan kedua orang tua terhadap remaja akan sangat mempengaruhi prilaku dalam semua tahap perkembangannya termasuk dalam pembentukan karakter mereka. Pola asuh yang 
spiritual atau menanamkan nilai-nilai agama di dalam mendirik dan mengasuh anak akan mampu menciptakan karakter yang baik pada diri remaja.

Spiritual parenting menurut Jahja (2011) adalah salah satu bentuk pola asuh yang dapat diterapkan orangtua untuk mengisi jiwa remaja-remaja menjadi individu yang hangat dan bersemangat dengan nilai-nilai spiritual. Remaja adalah insan spiritual, begitu pula dengan orangtua. Bersatunya insan spiritual semakin membuat kehidupan keluarga menjadi tentram. Cara paling awal ialah membangkitkan rasa ingin tahu remaja terhadap agamanya sendiri. Hal ini dapat dilakukan dengan memberikan contoh pada remaja bagaimana orangtua beribadah, sehingga remaja akan tertarik untuk mengetahui agama lebih lanjut. Orang tua juga mampu memenuhi semua kebutuhan emosi dan sosial remaja, menjadi panutan yang baik dihadapan remaja, menjadi orangtua yang spiritual dengan memimpin doa saat melakukan berbagai aktivitas bersama, orangtua tidak malu untuk meminta maaf kepada remaja jika mereka melakukan kesalahan, mengajak remaja mengunjungi keluarga atau tetangga yang tertimpa musibah, dan lain sebagainya.

Menurut psikolog Fauzil Adhim (dalam Jahja, 2011) menularkan nilai spiritual sama dengan menanamkan aspek dasar pendidikan moral pada remaja. Remaja akan lebih dahulu mengidentifikasikan dirinya dengan significant person (figur lekat remaja) yang dalam hal ini adalah orangtua. Sebagai pengasuh dan pembimbing dalam keluarga, orangtua sangat berperan meletakkan dasar-dasar berprilaku dan pendidikan agama bagi remaja-remajanya. Sikap, prilaku dan kebiasaan orangtua selalu dilihat, dinilai dan ditiru oleh remajanya yang kemudian semua itu secara sadar maupun tidak sadar diresapi kemudian menjadi kebiasaan pula bagi remaja. Hal tersebut karena remaja mengidentifikasikan dirinya pada orangtua sebelum mengidentifikasi orang lain (Papalia, 2008). Jadi peran orangtua dalam menjadikan diri mereka sebagai contoh panutan bagi remaja sangatlah penting. Pada masa-masa awal perkembangan remaja, remaja akan menghabiskan waktu mereka dengan melakukan imitasi dan identifikasi yang pesat terhadap lingkungan terdekat remaja yaitu orangtua. Orang tua merupakan role model bagi remaja di dalam lingkungan keluarga yang pertama mereka kenal. Jika orang tua jauh dari nilai-nilai spiritualitas, maka remajapun juga akan mengikuti jejak orangtuanya. Seperti kata pepatah, buah jatuh tidak jauh dari pohonnya. Remaja yang cerdas spiritual sebagian besar dilahirkan dari orang tua yang cerdas secara spiritual, begitu juga sebaliknya.

Sopidi (2007), dalam penelitiannya tentang perkembangan sikap keagamaan lewat pengasuhan, juga menyimpulkan bahwa sikap dan karakter beragama pada remaja ditentukan oleh pola asuh orangtua yang berlandaskan nilai-nilai agama dalam mendidik dan mengasuh remaja. Pola berpikir, perasaan dan karakter serta prilaku remaja yang didasarkan pada nilai-nilai agama adalah bentuk aktualisasi dari pola pengasuhan yang diterapkan oleh orangtuanya.

Keberhasilan keluarga membangun karakter remaja akan bermuara pada masyarakat yang warganya memiliki karakter yang baik, dan kegagalan keluarga dalam 
membentuk karakter remaja akan berakibat pada tumbuhnya masyarakat yang tidak berkarakter. Oleh karena itu setiap keluarga harus memiliki kesadaran bahwa karakter bangsa sangat bergantung pada pendidikan karakter remaja dirumah (Widajat, 2011). Matta, 2006.,Elmubarok, 2008.,Romlah, 2008. menjelaskan bahwa faktor yang mempengaruhi terbentuknya karakter yang baik pada individu remaja adalah lingkungan keluarga, lingkungan sosial dan lingkungan pendidikan. Karakter merupakan evaluasi kualitas tahan lama suatu individu tertentu atau disposisi untuk mengekspresikan perilaku dalam pola tindakan yang konsisten diberbagai situasi. Hal ini menunjukkan bahwa karakter memang terbentuk karena pola tindakan yang berstruktur dan dilakukan berulang-ulang. Pola yang berstruktur ini diperoleh remaja salah satunya melalui pola asuh yang diterapkan oleh orang tua.

\section{Kesimpulan}

Mendidik anak merupakan bagian terpenting dari orangtua agar dapat membentuk anak sesuai harapan. Tidaklah mudah dalam mendidik anak, hal ini berkaitan dengan bagaimana peran aktif orangtua dalam memberikan pola atau gaya dalam mendidik. Pola asuh yang diterapkan sangat berpengaruh dalam membentuk karakter anak. Karakter erat kaitannya dengan personality (kepribadian) seseorang, dimana seseorang dapat disebut orang yang berkarakter (a person of character) jika tingkah lakunya sesuai dengan kaidah moral. Keluarga mempunyai peranan dalam membentuk alam spiritual dan moral anak. Anak-anak saat ini adalah orang yang masih memerlukan bimbingan. Dengan demikian merupakan suatu kaharusan untuk memberikan perhatian yang intensif kepada mereka sejak mereka lahir ke dunia.

Upaya pembentukan karakter remaja salah satunya melalui pola asuh spiritual dalam keluarga. Spiritual parenting merupakan sistem pengasuhan remaja dengan paradigma menanamkan keimanan dan kesadaran rohani. Keluarga tumbuh dan berkembang secara unik dan berbeda-beda, namun terdapat pola-pola umum yang dijalani dengan variasi-variasi tertentu. Sistem dalam keluarga sangat mempengaruhi perkembangan seseorang. Salah satu sistem tersebut terletak dalam hubungan orangtuaremaja dalam konteks pengasuhan. Pengasuhan sendiri terkait dengan hubungan antara ayah dan ibu yang mempengaruhi bagaimana cara orangtua menghadapi anak. Karakteristik orang tua, tugas perkembangan keluarga, pola asuh yang dijalani, kompleksitas dinamika perubahan yang terjadi pada remaja, konflik yang terjadi antara remaja dengan orangtua dan konflik remaja dengan teman sebaya, serta tantangan orangtua dalam membimbing remaja dalam bidang akademik dan pendidikan seksualitas adalah faktor-faktor yang ikut memberikan kontribusi dalam pembentukan karakter remaja.

\section{Referensi}


Ben-Zur (2003). Happy Adolescents : The Link Between Subjective Well-Being, Internal Resorces and Parental Factors. Journal of Youth and Adolescence. Vol. 32, April, p 67-79.

Goldstein, S.E., Kean, P.E.D., Eccles, J.S. (2005). Parents, Peers, and Problem Behavior: A Longitudinal Investigation of the Impact of Relationship Perceptions and Characteristics on the Development of Adolescent Problem Behavior. Developmental Psychology, Vol. 41, No. 2, 401-413

Gutman L.M, Eccles J.S.(2006). Stage-Environment Fit During Adolescence: Trajectories of Family Relations and Adolescence Outcomes. American Psychology Association : Developmental Psychology, 2007, Vol.43, No.2, 522537.

Haring, S.B., Sabatteli, R. (1998). An Intergenerational Examination of Pattern of Individual and Family adjustment. Journal of Marriage and the Family; Nov 1998; 60, 4; ProQuest Religion pg. 903

Hurlock, E.B. (1978). Child development. Tokyo: McGraw-Hill Kogakusha Ltd.

Jahja, Yudrik. 2011. Psikologi Perkembangan. Jakarta: Kencana Prenada Media Group.

McGue M., Elkins ., Walden B., Iacono W.G.(2005). Perceptions of the ParentAdolescent Relationship: A Longitudinal Investigation. American Psychology Association : Developmental Psychology, Vol.41, No.6, 971-984.

Monks, F.J., Knoers, A. M. P., Haditono, S. R. (1991) Psikologi perkembangan : Pengantar dalam berbagai bagiannya (cetakan ke-7). Yogya: Gajah Mada University Press.

Papalia, D.E., Olds, S.W., \& Feldman, R.D. 1986. A Child's World, Infancy Through Adolescence. 9th edition. New York: McGraw Hill.

Perrino, T., Soldevilla, A.G., Pantin, H. Szapocznik, J. 2000. The Role of Families in Adolescent HIV Prevention:A Review. Clinical Child and Family Psychology Review, Vol. 3, No. 2, 2000

Pettit, G.S., Yu, T., Dodge, K.A., Bates, J.E. (2009). A Developmental Process Analysis of Cross-Generational Continuity in Educational Attainment. Merrill-Palmer Quarterly, vol. 55, no. 3

Pemda Tingkat I Bali, Proyek Bantuan Lembaga Pendidikan, Catur Yadnya, 1985

Rice, F.P., Dolgin, K.G. (2008). The Adolescent. Development, Relationships and Culture. New York : Pearson Education Inc.

Santrock, J. W. 2002. Perkembangan Masa Hidup. Jakarta: Erlangga.

Sopidi, 2007. Jurnal Al-Tarbiyah edisi XX, Vol 1 Juni 2007. Stain Cirebon.

Sudrajat, A. 2010.Tentang Pendidikan Karakter. 
Psikobuletin: Buletin Ilmiah Psikologi

Vol. 2, No. 2, Mei, 2021 (71-81)

e-ISSN : $2720-8958$

DOI : 10.24014/pib.v2i2.11373

Voorhis, F.L. (2003). Interactive Homework in Middle School: Effects on Family Involvement and Science Achievement. The Journal of Educational Research, Vol. 96, No. 6 (Jul. - Aug.), pp. 323-338

Widajat, Wahyu. 2011. Buletin Pendidikan Karakter. Surabaya

Wilkinson. I. (1993). Child and Family Assesment. Clinical Guidelines for Pratitioner.2nd ed. London : Routledge.

Wills, T.A., Yaeger, A.M. (2003). Family Factors and Adolescent Substance Use: Models and Mechanisms Thomas. Current Directions in Psychological Science. Volume 12, Number 6, December. 